Article

\title{
A Humboldtian Critique of the University of the Philippines as the Flagship of Philippine Higher Education (Part II)
}

\section{F.P.A. Demeterio III Roland Theuas DS. Pada}

\begin{abstract}
For the Philippines to benefit from the ASEAN integration and globalization, in general, it must be able to mould highly educated citizens who can proactively engage themselves with the national, regional and international knowledge economies. ${ }^{1}$ The Philippines has nine research universities that presumably lead its approximately 2,500 higher educational institutions in moulding these needed citizens. These nine research universities are the eight autonomous constituent units of the University of the Philippines and De La Salle University. The idea of the modern research university was invented more than 200 years ago in Berlin by the philosopher, linguist, humanist and statesman Wilhelm von Humboldt (1767-1835). Around 1850, American educational leaders started to appropriate Humboldt's ideas to establish the American research universities. As the University of the Philippines is an American creation and at the same time the flagship institution of Philippine higher education, this paper used the Humboldtian philosophy of education as well as its American rendition in looking at the soundness of this university's claim to as a research university. To attain this goal, this paper has three substantive sections: 1) a discussion on Humboldt's philosophy of education, 2) a discussion on the American translation of Humboldt's philosophy of education, 3) a critique of the foundational principles of the University of the Philippines as a research university.
\end{abstract}

Keywords: Wilhelm von Humboldt, Humboldtian Research University, American Research University, University of the Philippines, Philippine Higher Education

${ }^{1}$ Philip Altbach, "The Past, Present, and Future of the Research University" in The Road to Academic Excellence: The Making of World-Class Research Universities, ed. by Philip Altbach \& Jamil Salmi, (Washington, D.C.: The World Bank, 2011), 11.

(C) 2019 F.P.A. Demeterio III and Roland Theuas DS. Pada

https://www.kritike.org/journal/issue 24/demeterio\&pada june2019.pdf

ISSN 1908-7330

$(c c)$ BY-NC-ND 


\section{The University After the Liberation from American Colonization}

s already mentioned, this period spanned from 1946, the end of the
American colonial rule in the Philippines, to 1972, the year when UP
was transformed into a system. The length of this period is 26 years. The key documents that were analyzed under the liberation period of UP are: 1) the 1951 inaugural speech of the University President Vidal Tan; 2) the 1958 inaugural speech of the University President Vicente Sinco; 3) the document Research Organization in the University that was released by the Office of the Vice President for Academic Affairs around 1960; 4) The United States Office of Mission to the Philippines' The Tenth Milestone: a Report of a Decade of U.S. Assistance to Public Education in the Philippines of 1962; 5) Walter Dyde's A Report on Graduate Education in the Philippines of 1962; 6) the 1962 inaugural speech of the University President Carlos Romulo; 7) Guadalupe ForesGanzon's essay "Research" that is part of the papers and proceedings of the 1966 University of the Philippines Faculty Conference; 8) Alfredo Morales's essay "Our Goal of Quality Education" that is also part of the said 1966 conference; 9) Victor Valenzuela's essay "Graduate Education" that is also part of the said 1966 conference; and 10) the 1969 inaugural speech of University President Salvador Lopez.

The 1951 Inaugural Speech of Tan: Dr. Vidal Tan, a mathematician from Cornell University and Chicago University, was president of the university from 1951 to 1956 . He mentioned in his inaugural address that the fourth function of a state university is "to serve as our (the country's) principal contributor to the world's stock of knowledge." He stated: "Fortunately, UP, in spite of the meager support it receives from the government, in spite of the heavy faculty teaching load which has been a constant source of embarrassment before visiting professors from famous institutions abroad, has shown notable contributions in such fields as medicine, agriculture, forestry, pharmacy, dentistry, chemistry, archeology, nursing, history and other fields." Tan's statement hinted that in the university, there persisted the tension between teaching and research.

The 1958 Inaugural Speech of Sinco: The Lawyer Vicente Sinco was president of the university from 1958 to 1962 . He was a former exchange professor to Tokyo Imperial University and Waseda University. He made an almost Humboldtian statement when he said: "A university is distinctively an association of scholars and students engaged in the search for knowledge, in the work of advancing the frontiers of knowledge, in the discovery of new learning, in the exploration of the higher spheres of thought to improve or to replace ideas that have ceased to be valid and true, and, above all, in the creation and cultivation of the spirit of discovery." But this Humboldtian trace dissipated immediately when Sinco elaborated: "Hand in hand with

(c) 2019 F.P.A. Demeterio III and Roland Theuas DS. Pada https://www.kritike.org/journal/issue 24/demeterio\&pada june2019.pdf ISSN 1908-7330 


\section{A HUMBOLDTIAN CRITIQUE}

research in a university, teaching comes as an inseparable companion, systematic, inspiring, stimulating, and thought-provoking. That kind of teaching is the unmistakable reflection of the teacher's application to learn and the result of the discipline of research."

The Document Research Organization in the University: The document Research Organization in the University that was released by the Office of the Vice President for Academic Affairs is actually undated. But its internal references suggest that it was published around 1960. The document admitted that for the past 50 years of the existence of the university, it has focused on teaching (i). But the document desired to operationalize the research thrust of Sinco by clarifying first the current configuration of the various research centres within the university (i). The document mentioned an already remarkable number of research centres, yet these remained facilities for faculty members to pursue research and attract external funding.

The 1962 Tenth Milestone Report of the United States Office of Mission to the Philippines: Paul Summers and James Ingersoll headed the United States Office of Mission to the Philippines when this report was made. Section IV of this report zeroed in on the impact of American assistance to Philippine higher education, and almost half of this section talked about UP. The section mentioned six challenges that UP should face, and three of these are directly relevant to the concern of this project: 1) finances, 2) faculty members, and 3) advanced education and research. Concerning finances, the report stated: "It is apparent that the University cannot expand its offerings at the very much more expensive upper division and graduate levels, or support research activities commensurate with the nation's needs, without a very substantial increase in the financial support by the National Government." 2 Concerning faculty members, the report emphasized: "The problem of developing highly trained faculty members is an extremely difficult one for the Philippines. The University can find very few men and women to appoint, especially to senior staff positions, from the staffs of other institutions in the Philippines. Faculty members with advanced degrees must, for the most part, be trained abroad." ${ }^{3}$ Concerning advanced education and research, the report hinted that the United States of America and developed democratic countries of the west are interested that UP transition from being a teaching university into an American-style research university so that it can better serve not only the Philippines but Southeast Asia and

\footnotetext{
${ }^{2}$ United States Office of Mission to the Philippines, The Tenth Milestone: A Report of a Decade of U.S. Assistance to Public Education in the Philippines, 1952-1962. (Manila: United States Office of Mission to the Philippines, Agency for International Development, 1962), 85.

${ }^{3}$ Ibid., 86.

(c) 2019 F.P.A. Demeterio III and Roland Theuas DS. Pada

https://www.kritike.org/journal/issue 24/demeterio\&pada june2019.pdf

ISSN 1908-7330
}

$((c))$ BY-NC-ND 
even the Far East. ${ }^{4}$ These three challenges suggest that UP in the early part of the 1960s still remained a teaching university.

The 1962 Report on Graduate Education in the Philippines of Dyde: Dyde, a former Vice President for Academics of the University of Colorado, was the adviser on graduate education of the United States Agency for International Development and was assigned to UP when he produced this voluminous report on the university's graduate education. Dyde's overall assessment of UP is that it was a "predominantly ... teaching institution with a modest program of graduate education" situated in a national context of depressed academic standards and a strong preference for professionalvocational training. ${ }^{5}$

He mentions not less than four reasons why the university was not able to transition to an American-style research university. First is the difficulty in placing sufficient numbers of doctors and high-ranking academics in the university. ${ }^{6}$ In 1961, Dyde noted that the ratio among doctors, masters and bachelors in UP was $14.0 \%-37.8 \%-46 \%$, while in the 25 American North Central Association universities, the ratio a decade earlier was already $43.0 \%-37.0 \%-20.0 \% .^{7}$ At that time, these doctoral degrees had to be obtained in America or other places abroad, and for Filipino academics, such degrees were simply too expensive. Dyde also noted that the ratio among high ranking and low-ranking academics in UP was $18.6 \%-81.4 \%$, while in the American North Central Association universities, the average ratio was $48.8 \%-51.2 \% .^{8}$

Second is the salary of and mandatory retirement age of faculty members of UP. Dyde stressed: "the vulnerability to offers of employment from outside the University of those with advanced training in such fields as science, engineering, and business is so great that the importance of improving the salary scale of the University is again underlined." 9 Professors with the right degrees, and teaching and research experiences were made to retire at age 65. Dyde argued: "a university professor in the Philippines with the highest academic qualifications and with long experience is such a valuable asset not only educationally but purely commercially, considering the cost of his production, that no amount of competent working time should be wasted." 10

${ }^{4}$ Ibid., 87

${ }^{5}$ Walter Dyde, A Report on Graduate Education in the Philippines, (Quezon City: Graduate College of Education, University of the Philippines, 1962). pp. i-ii.

${ }^{6}$ Ibid., III-5 \& III-3.

7 Ibid., III-5

${ }^{8}$ Ibid., III-3.

${ }^{9}$ Ibid., III-12.

${ }^{10}$ Ibid., IV-4.

(c) 2019 F.P.A. Demeterio III and Roland Theuas DS. Pada https://www.kritike.org/journal/issue 24/demeterio\&pada june2019.pdf ISSN 1908-7330 


\section{A HUMBOLDTIAN CRITIQUE}

The third is the financial considerations. Transitioning into an American-style research university "will require expenditures of an order of magnitude far beyond the unit costs for undergraduate instruction."11 Dyde made an estimate that the 1960s budget of UP might be at par with the pre-Second World War budget of the American research universities, but times had already changed and federal, corporate and private funding had been pumped into the American-style research universities. ${ }^{12}$

Fourth is the long-term effect of the earlier decisions of UP to expand "horizontally into almost every professional curriculum."13 Such mode of expansion "strained the resources of the university so that vertical expansion into advanced graduate work has been retarded."14 Despite these four observations, Dyde believes that the time is ripe for UP to put up a researchbased graduate education to start its transition into a research university. ${ }^{15}$

The 1962 Inaugural Speech of Romulo: Writer, soldier and diplomat, Carlos Romulo was president of the university from 1962 to 1968. He studied at Columbia University. In his inaugural speech, he commented on the concept of research during the presidency of Bartlett as merely "research for instruction, not for the sake of knowledge itself or for any other service." He claimed: "Today, the research function has come to its own alongside with teaching; we have, in addition, dispensed considerable community and extension services, and, as a regional centre, contributed directly to the spread of universal and specialized knowledge in Southeast Asia and beyond." In his five-year development plan for the university, there are two things that resonated with the model of the American research university: his plan to develop the graduate programs of the university, and his intention that such development would be parallel with his envisioned intensification of research. To what extent was Romulo successful in these two elements of his five-year development plan is something that must be answered by other archival materials. But in as far as the succeeding documents that we are going to examine are concerned, nothing much happened out of these otherwise brilliant and almost Humboldtian plans.

The 1966 "Research" of Fores-Ganzon: As already mentioned, Fores-Ganzon's essay is part of the papers and proceedings of the 1966 University of the Philippines Faculty Conference. She mentioned three important documents that served as the background to her essay: 1) the 1961 modification of the mandate of UP; 2) a 1962 report of an Ad Hoc Committee on Research Promotion; and 3) the Five-Year Development Plan, 1963-68, that

\footnotetext{
${ }^{11}$ Ibid., I-7.

${ }^{12}$ Ibid., IV-2.

${ }^{13}$ Ibid., I-36a.

${ }^{14}$ Ibid.

${ }^{15}$ Ibid., I-13-15.
}

(C) 2019 F.P.A. Demeterio III and Roland Theuas DS. Pada https://www.kritike.org/journal/issue 24/demeterio\&pada june2019.pdf ISSN 1908-7330 
was crafted under the leadership of Romulo. The 1961 modification of the mandate of UP pertains to the addition of the mandate on research on the original 1908 mandate on teaching: "to encourage and undertake research and contribute to the growth of and dissemination of knowledge." 16

The 1962 report of the Ad Hoc Committee was intended as an input for the research aspects of the Five-Year Development Plan. The report noted that as of 1962, UP was not prepared to undertake its research mandate. ${ }^{17} \mathrm{It}$ also noted that there were four basic hindrances for the undertaking of this research mandate: 1) the inadequate annual budgetary allocation for research; 2) the heavy teaching load of the faculty members; 3 ) the low ratio of research-trained faculty members who were unfortunately also mostly tied to administrative assignments; and 4) the inadequacy of the university's library, laboratories, equipment and supplies. ${ }^{18}$

The Five Year Development Plan, partly in response to the findings of the Ad Hoc Committee, made the following strategies for research: 1) a budgetary allocation that would allow $10 \%$ to $15 \%$ of departmental functions to be devoted to research; 2) organization of properly equipped research centres; 3) transformation of existing institutes into research centres that will treat teaching as incidental activity to their primary function of undertaking research; 4) the provision for special assistance to departments with low research productivity; 5) gradual increase of the allocation for research until it will stabilize at $20 \%$ of the total annual budget of the university; 6) Prioritization of projects that closely relate to national development plans or programs; and 7) the creation of 100 new academic positions, specifically, teaching staff to relieve research competent staff from teaching. ${ }^{19}$

In 1966, it was too early for Ganzon to make a definitive assessment of the initial effects of the Five-Year Development Plan. Her suggestion that the university should collaborate with other government agencies and even the private sector in addressing "problems of modern-day living" conformed to the idea of a Humboldtian research university. ${ }^{20}$ But the way she laboured so much problematizing the impact of an increased research capacity of the faculty members to their current level of teaching capacity betrays the fact that she, the Five-Year Development Plan, and the university as a whole were unaware that it is actually possible to unify teaching and research in a research university. ${ }^{21}$

${ }_{16}$ Guadalupe Fores-Ganzon, "Research" in Reappraisal and Rededication: Papers and Proceedings, 1966 UP Faculty Conference, ed. by Hernando Abaya, (Quezon City: University of the Philippines, 1966), 105.

${ }^{17}$ Ibid.

18 Ibid., 106.

${ }^{19}$ Ibid., 110.

${ }^{20}$ Ibid., 118

${ }^{21}$ Ibid., 112-115.

(c) 2019 F.P.A. Demeterio III and Roland Theuas DS. Pada https://www.kritike.org/journal/issue 24/demeterio\&pada june2019.pdf ISSN 1908-7330 


\section{A HUMBOLDTIAN CRITIQUE}

The 1966 "Our Goal of Quality Education" of Morales: As already mentioned, Morales' essay is part of the papers and proceedings of the 1966 University of the Philippines Faculty Conference. The already mentioned Five Year Development Plan, 1963-68, again served as a background to this essay. Morales made a pun out of the idea of quality and equality. This pun revolved around justifying the place of teaching amidst the growing emphasis on research. Equality, thus, referred to both equality in terms of teaching and research. Morales offered a counter-polemic, or justification of teaching as a response to the other conference papers made for the sake of research. He asserted that the Five-Year Development Plan ought to keep in mind the major importance that should be given to the objective of having high teaching standards. ${ }^{22}$ He maintained that the university should uphold quality education by providing excellent quality instruction and professional training. This statement deviated from the Humboldtian idea of unifying teaching and research.

Morales revealed a disturbing development in the university's efforts of setting up doctoral programs. The essay mentioned that the university wanted to have its first homegrown doctors of philosophy by 1968, the terminal year of the Five Year Development Program. ${ }^{23}$ But it appeared that such first batch of doctors would come from the University Science Teaching Center, a unit that was established by the university with the assistance of the Ford Foundation. The housing of doctoral programs in a unit named as such already suggested that such programs maintained the dichotomy between teaching and research. Another more disturbing feature of the centre was that it was steeped with Jerome Bruner's pedagogical philosophy called "new educational technology." 24 Such pedagogical philosophy did not only fall short from the Humboldtian educational philosophy but was more so a pedagogical philosophy what was primarily intended for children's education. The university's infatuation with Bruner's pedagogical philosophy reinforced its dichotomous treatment of teaching and research.

The 1966 "Graduate Education" of Valenzuela: As the title implies, Valenzuela's speech is loaded with emphasis on improving the quality of graduate education in the university to respond to the growing needs of the industry and the academia. ${ }^{25}$ While the emphasis may give one an impression that Valenzuela is following a Humboldtian vision of a research-centric university, his concerns are mostly driven by administrative requirements

${ }^{22}$ Alfredo Morales, “Our Goal of Quality Education” in Reappraisal and Rededication, 120.

${ }^{23}$ Ibid. p.128.

${ }^{24}$ Ibid. pp. $128-129$.

${ }^{25}$ Victor Valenzuela, "Graduate Education" in Hernando Abaya, Editor. Reappraisal and Rededication, (Quezon City: University of the Philippines, 1966), 131.

(c) 2019 F.P.A. Demeterio III and Roland Theuas DS. Pada

https://www.kritike.org/journal/issue 24/demeterio\&pada june2019.pdf

ISSN 1908-7330

(cc) BY-NC-ND 
rather than a vision of a research university, for, on the one hand, he highlights the immediate demand of industries such as business administration, agriculture, economics, education, engineering, home economics, hospital administration, public administration, social work, demography and statistics, as a response to the growing needs of the labour industry and government work, ${ }^{26}$ while on the other hand, he also chimes in on expanding and improving the graduate programs ${ }^{27}$ to respond to a growing specialized need of labour, not only in the labour industry but also specifically in the University itself.

Despite this special emphasis on filling in the ranks of labour, Valenzuela's envisioned improvements on graduate programs bring about some proposals that could have benefited the research thrust of the University. Unlike the recent emphasis of contemporary universities to promote graduate education for the sake of fulfilling accreditation criteria, Valenzuela's emphasis on graduate education was aimed at improving and providing specialized skills to respond to the growing demand of the workforce and national concerns. Incidentally, Valenzuela saw the importance of research in developing these skillsets and made several suggestions on how research can improve the graduate program of the University. One of these suggestions was to integrate the admission and graduation requirements, that adds emphasis to the "nature and depth of thesis and dissertation." ${ }^{28} \mathrm{He}$ also stressed on a closer "tie-up" between faculty research and graduate teaching, to disseminate creative and investigative research work in graduate teaching. ${ }^{29}$ Valenzuela emphasized that a faculty member should also transfer his or her knowledge of an existing research work through tutelage and that "the money invested in research grants for faculty members should be made to pay off in terms of education and training of graduate students." 30

Another interesting development found in Valenzuela's thoughts on improving the graduate programs of the University is his proposal to create an interconnected graduate program. His proposal was to investigate the possibility of a collaboration with other universities that offer courses and programs that are not available in UP. ${ }^{31}$ He suggests a sharing of resources with other universities to supplement weaknesses in areas that are in need of development, while at the same time, extending the expertise to improve the graduate program of other universities. This is perhaps, the most

\footnotetext{
${ }^{26}$ Ibid.,

${ }^{27}$ Ibid., 132.

${ }^{28}$ Ibid., 133

${ }^{29}$ Ibid.

${ }^{30}$ Ibid.

${ }^{31}$ Ibid., 134.
}

(c) 2019 F.P.A. Demeterio III and Roland Theuas DS. Pada https://www.kritike.org/journal/issue 24/demeterio\&pada june2019.pdf ISSN 1908-7330 


\section{A HUMBOLDTIAN CRITIQUE}

Humboldtian suggestion that Valenzuela has made in this speech. This vision of shared resources pre-dates the competitive nature of universities to simply out-rank other universities with their programs. Not only does this pronouncement provide an avenue for fostering a broad array of research programs, but it is also a move closer to a vision of a unified thrust of research that is much more akin to Humboldt's vision.

The 1969 Inaugural Speech of Lopez: Literary critic and diplomat Salvador Lopez was president of the university from 1969 to 1975. In his inaugural speech, he said: "The university is a single, indivisible community of scholars composed of professors and students jointly engaged in the search for goodness, truth and beauty." 32 This sounds like a Humboldtian statement, which is followed by another even more remarkable statement: "While students improve their scholarship under the guidance of professors, the latter, in turn, heighten the quality of their own scholarship in the very process of teaching, often through intellectual interaction with their students." 33 But Lopez did not elaborate on how these visions can be achieved or how the university could transition from a teaching university into a research university.

Summation: The story of UP during its period of liberation from American colonialism is a story of a teaching university that rose from the devastation of the Second World War. In its 1961 Code, it recognized research as the second function of the university. It took advantage of the rising demand in the country for professionals with graduate degrees and expanded its graduate programs and even started to offer doctoral programs. It also started to problematize, at least at the hypothetical and theoretical level, the negative impact of the research activities of the faculty members on their teaching activities. But instead of unifying teaching and research, at least at the graduate level, the university opted to maintain their dichotomy. Its graduate programs persisted in their being non-research based and became entangled with the non-Humboldtian pedagogical philosophy of Bruner. Towards the end of the liberation period of UP, the anti-American sentiments of the students and citizen unrests steered the university farther away from the chance of embodying the American-style research university. The liberation period of the university was concluded with another devastation, which is the political, cultural, intellectual and spiritual havoc spawned by the declaration of Martial Law.

\footnotetext{
32 Salvador Lopez, "The University as Social Critic and Agent of Change" in The Role and Mission of the University: Inaugural Addresses of the Presidents of the University of the Philippines, ed. by Consuelo Fonacier, (Quezon City: University of the Philippines Press, 1971) 191.

${ }^{33}$ Ibid.
}

(c) 2019 F.P.A. Demeterio III and Roland Theuas DS. Pada

https://www.kritike.org/journal/issue 24/demeterio\&pada june2019.pdf

ISSN 1908-7330

(c) BY-NC-ND 


\section{The University as a System}

As already mentioned, this period spanned from 1972, the year when UP was transformed into a system, to 2008, the year when the university was officially named a national university and a research university. The length of this period is 36 years. The key documents that were analyzed under this period are: 1) the Presidential Decree 58 of 1972 that amended the University Charter and restructured the university into system; 2) Oscar Evangelista's essay "Lopez's Beleaguered Tenure: Barricades on Campus at the Peak of Student Discontent" of 1985; 3) Jose Endriga's essay “Corpuz and Soriano's Bifocal Administrations: toward a Realignment of the Academe to National Realities under a Crisis Government" of 1985; 4) Leslie Bauzon's essay "Angara's Tough Minded Leadership: the Diamond Jubilee Highlighted by Reform of the University System" of 1985; 5) the 1993 summative speech of the University President Jose Abueva; 6) the 1994 inaugural speech of the University President Emil Javier; 7) the 1998 vision paper of Francisco Nemenzo that led to his appointment as University President; 8) the document Shaping our Institutional Future: a Statement on Faculty Tenure, Rank and Promotion that was released by the Office of the Vice President for Academic Affairs in 2004; and 9) the 2005 inaugural speech of the University President Emerlinda Roman.

The 1972 Amendment of the University Charter (Presidential Decree 58): The legislation that amended the University Charter was done two months after the Martial Law was declared. This explains why it was not a product of the Philippine legislative body. This legislation transformed the university into a system and identified its Los Baños campus as the first autonomous unit of such system (Presidential Decree 58, Section 1). The main motive for this dramatic transformation is for the newly established autonomous unit, UP Los Baños, to assist the country's agrarian reform in terms of agricultural and policy research. The Humboldtian unity of the goals of the university and of the state, at least in as far as UP Los Baños is concerned, is very discernible in this legislation, but not the other Humboldtian unities, particularly those of teachers and students, and of teaching and research.

The 1985 "Lopez's Beleaguered Tenure" of Evangelista: Evangelista's essay is part of the book University of the Philippines: The First 75 Years (1908-1983) that was edited by Oscar Alfonso. The essay mentions several changes and developments that enhanced the research capacities of the university's faculty members during the rest of the presidency of Lopez. In 1972, the teaching load of the faculty members was finally reduced from 15 hours per week to 12 hours per week, which is the current norm in the

(c) 2019 F.P.A. Demeterio III and Roland Theuas DS. Pada

https://www.kritike.org/journal/issue 24/demeterio\&pada june2019.pdf

ISSN 1908-7330

(cc) BY-NC-ND 


\section{A HUMBOLDTIAN CRITIQUE}

university. ${ }^{34}$ In this same year, a policy was made stipulating that only master degree holders with a rank of assistant professors are qualified for tenure. ${ }^{35}$ In the same year also, which is just a decade after Dyde presented his report, the university registered a remarkable growth in graduate education: 142 masteral programs and 23 doctoral programs. ${ }^{36}$ In 1974, dramatic improvements were noticed in as far as the number of professorial chairs is concerned: an increase from 6 in 1969 to a total of 79 in the said year, aside from the creation of faculty appointments as artists-in-residence, writers-inresidence, and musicians-in-residence. ${ }^{37}$

The 1985 "Corpuz and Soriano's Bifocal Administrations" of Endriga: Endriga's essay is also part of the same book edited by Alfonso. This essay tells the story of further changes and developments that enhanced the research and extension capacities of the university's faculty members, during the presidencies of Onofre Corpuz and Emanuel Soriano, until the university itself came face to face with a crucial problem that Humboldt himself faced prior to the establishment of the University of Berlin. The essay attests that in 1975 , the university already had a total number of 144 masteral programs and 29 doctoral programs. ${ }^{38}$ This will grow further to 295 and 83, respectively, after just two years. ${ }^{39}$ In 1979, two more autonomous units of the university system were established: UP Visayas, and the Health Sciences Center, which later on evolved into UP Manila. ${ }^{40}$ Endriga noted the increased internal funding for research as well as the easy availability of funds from external agencies, both local and international. ${ }^{41}$ Endriga explained that the proliferation of externally funded research projects gave birth to a category of research projects called "mission-oriented" research, "which by definition meant that it was addressed to the solution of some of the society's pressing problems." ${ }^{2}$ Endriga also documented the increasing number of consultancy engagements that faculty members accepted from the government, corporations and international organizations. ${ }^{43}$ Endriga wrote: "all the

\footnotetext{
${ }^{34}$ Oscar Evangelista, “Lopez's Beleaguered Tenure: Barricades on Campus at the Peak of Student Discontent" in University of the Philippines: The First 75 Years (1908-1983), ed. by Oscar Alfonso (Quezon City: University of the Philippines, 1985), 450.

${ }^{35}$ Ibid., 491.

${ }^{36}$ Ibid., 484.

37 Ibid., 490.

${ }^{38}$ Jose Endriga, “Corpuz and Soriano's Bifocal Administrations: toward a Realignment of the Academe to National Realities under a Crisis Government," in University of the Philippines: The First 75 Years (1908-1983), ed. by Oscar Alfonso, (Quezon City: University of the Philippines, 1985), 515.

${ }^{39}$ Ibid.

${ }^{40}$ Ibid.

${ }^{41}$ Ibid., 523-524.

42 Ibid., 524.

${ }^{43}$ Ibid., 525.

(c) 2019 F.P.A. Demeterio III and Roland Theuas DS. Pada

https://www.kritike.org/journal/issue 24/demeterio\&pada june2019.pdf

ISSN 1908-7330
}

(c) BY-NC-ND 
preceding conjures an image of a university faculty extremely busy with research and extension services and hence forced to relegate teaching into the background." 44 In other words, without the Humboldtian framework, the dramatic improvements of the university faculty members' capacities for research and extension had brought the university to an old situation where conflict exists between teaching, and research and extension.

The 1985 "Angara's Tough-Minded Leadership" of Bauzon: Bauzon's essay is also part of the same book edited by Alfonso. It was, however, written somewhere during the middle of the term of the University President Edgardo Angara. Thus, it only mentions at least one development pertaining to the university faculty members' research and extension activities. Bauzon wrote that Angara established the Diamond Jubilee Consultancy Project in 1983 to market and manage the increasing number of consultancy engagements of the university's faculty members. ${ }^{45}$ The management fees scrounged by this project were able to establish funds for the research capacity building and actual research projects of the faculty members. Thus, the time and energy lost by the university for consultancies were compensated by a fund that would further increase the research capacities and activities of the faculty members. The strategy may be novel, but it failed to address the problem that already emerged during the presidencies of Corpuz and Soriano: the conflict between teaching, research and extension.

The 1993 Summative Speech of Abueva: The political scientist Abueva was president of the university from 1987 to 1993 . He studied at the University of Michigan. In his summative speech of 1993 he mentioned that the university is the only institution in the country that can be considered a graduate university, for the reason that one in every five of its students is a graduate student, as well as for the reason that the university has "175 master's programs and over 50 doctoral programs." 46 Among all the documents examined in this paper, Abueva's speech is the first one to refer to UP as a research university. ${ }^{47}$ But his reasons for doing so are only based on what for him was a high level of "faculty involvement and productivity in scientific and scholarly research and in artistic creativity and production, and. . . investment and expenditures in research. ${ }^{48}$ Nowhere in this document can

\footnotetext{
44 Ibid., 526.

45 Leslie Bauzon, “Angara's Tough-Minded Leadership: The Diamond Jubilee Highlighted by Reform of the University System" in University of the Philippines: The First 75 Years (1908-1983) ed. by Oscar Alfonso, (Quezon City: University of the Philippines, 1985), 569.

${ }^{46}$ Jose Abueva, "Summing Up my Years as UP President: Leadership, Innovation and Reform (1987-1993)" Reinventing UP as the National University: Learning for Truth, Leadership and Social Transformation (Quezon City: University of the Philippines, 2008), 244.

47 Ibid., 245.

${ }^{48}$ Ibid.
} 


\section{A HUMBOLDTIAN CRITIQUE}

we find the Humboldtian unities of teachers and students, and of teaching and research.

The 1994 Inaugural Speech of Javier: The agricultural scientist Javier was president of the university from 1993 to 1999. He implies a classic American research university when he said: "We will maintain our undergraduate courses as models of the nation's educational system and proceed to strengthen our graduate and research programs." ${ }^{49}$ But his elaboration on research never went beyond the Humboldtian unity of the goals of the university and of the state: "we have to push forward the frontiers of science and accelerate the development of our capacity in such new fields as materials science, computer and information science, molecular biology and biotechnology. We must generate and adopt new knowledge not only to satisfy our intellectual hunger but also to achieve a high quality of life for Filipinos." 50

The 1998 Vision Paper of Nemenzo: The political scientist Nemenzo was president of the university from 1999 to 2005. He studied at the University of Manchester. As his inaugural speech was not published, this paper analyzed the vision paper that he prepared that led to his appointment as University President. He articulated the anxieties of the members of the university due to the fact that the leading universities in the ASEAN region have already left behind the ratings of UP, and that the said university seemed to be unable to actively engage with the global knowledge economy. He said: "our urgent task today is not only to reverse this trend but also to adapt the university to a new global political economy in which knowledge power is the most important factor of production and the brainworkers are the most crucial segment of the workforce." ${ }^{51} \mathrm{He}$ envisioned the university to lean towards an American model of a research university: "It is expected to produce leaders in the major professions and academic disciplines. It is also expected to generate new knowledge through research activities of its faculty and graduate students. In recent times, the extension has been added to the university's essential function." 52

The 2004 Document Shaping our Institutional Future: A Statement on Faculty Tenure, Rank and Promotion: In 2004, UP as a system already had seven autonomous constituent units. To maintain a system-wide standard in as far as the qualifications and achievements of faculty members, the Office

\footnotetext{
${ }^{49}$ Emil Javier, "U.P. in the Service of the Nation: Recapturing the Sense of National Purpose." in The Investiture of Dr. Emil Q. Javier as Sixteenth President of the University of the Philippines (Quezon City: University of the Philippines, 1994), 25.

${ }^{50}$ Ibid., 25-26.

${ }^{51}$ Francisco Nemenzo, "UP into the 21st Century" in UP into the 21st Century and other Essays (Quezon City: University of the Philippines Press, 2000), 2-3.

52 Ibid.

(c) 2019 F.P.A. Demeterio III and Roland Theuas DS. Pada

https://www.kritike.org/journal/issue 24/demeterio\&pada june2019.pdf

ISSN 1908-7330
}

(c) BY-NC-ND 
of the Vice President for Academic Affairs deemed it necessary to come up with this document. Among other things, this document describes the job descriptions of the university's instructors, assistant professors, associate professors and full professors. ${ }^{53}$ An overview of these descriptions is the statement: "once appointed to a rank, the faculty member is expected to teach as well as possible, build up a productive record of research or creative work, and engage actively in activities that serve the University and the larger community." 54 In other words, the document generates a trichotomy teaching, research and extension. Although the document emphasized the Humboldtian unity of the goals of the university and of the state, it does not convey the Humboldtian unities of teaching and research, and teachers and students.

The 2005 Inaugural Speech of Roman: The business and administration professor Roman was president of the university from 2005 to 2011. She studied in UP. Roman echoed the concern of Nemenzo for the university to catch up with the statures of the national universities in Asia, such as "the National University of Singapore, the University of Indonesia, the University of Malaya in Malaysia, Chulalongkorn University in Thailand, Tokyo University, and Seoul National University," in as far as "spearheading" their respective countries' "quest for knowledge and keeping abreast of advances in different fields of knowledge worldwide." 55 Roman asserted that UP is the leading research university in the country. ${ }^{56}$ However, when she elaborated what made the university so, she was not able to strongly emphasize the link between graduate education and research: "the number of graduate courses we offer, our upgraded and modernized teaching and research laboratories and other facilities some of which. . . are now of world-class standards, and our research and publications record. . . has undoubtedly made UP the leading research university in the country." 57

Summation: The story of UP during the period of its transformation into a system that would eventually be composed of eight autonomous units appears to be a story of a teaching university that has continued to grow and decentralized its administration. It has implemented its current teaching load of 12 units per term to give room for research and extension. It has multiplied its graduate programs. It has experienced, for the first time, the proliferation of external research grants coming from the national government and other

\footnotetext{
${ }^{53}$ Office of the Vice President for Academic Affairs of the University of the Philippines, Shaping our Institutional Future: A Statement on Faculty Tenure, Rank and Promotion (Quezon City: University of the Philippines, 2004), 17-19.

${ }^{54}$ Ibid., 17.

${ }^{55}$ Emerlinda Roman, "The University of the Philippines: A National University in the 21st Century," in The University of the Philippines Gazette, 36:3 (July-September 2005), 46.

${ }^{56}$ Ibid., 47.

${ }^{57}$ Ibid.
}

(c) 2019 F.P.A. Demeterio III and Roland Theuas DS. Pada https://www.kritike.org/journal/issue 24/demeterio\&pada june2019.pdf ISSN 1908-7330 


\section{A HUMBOLDTIAN CRITIQUE}

international funding agencies. Consequently, the problematization about balancing the teaching and research functions of the faculty members, which in the preceding period was merely a hypothetical and theoretical musing, became a matter of immediate concern. The actual term "research university," for the first time, crept into the vocabulary of the university. But the term's presence in the university's vocabulary did not guarantee that the university administrators adequately grasped the meaning of such a term. The documents show that during this period, the university continued to fail to unify teaching and research at least at the graduate level. During this period, the university felt that it was left behind by the other leading ASEAN and Asian universities, although it was not able to realize that such surging universities were dyed in the wool research universities. This time, there was no devastation that closed the period of the university's transition into a system. Instead, the conclusion of this period could be recounted as a time of preparation for the first centenary of the university and of lobbying for its legislated transition into a national research university.

\section{The University's Transition into a Research University}

As already mentioned, this period spanned from 2008, the year when UP was officially named a national university and a research university, to the present times. The key documents that were analyzed under the period when the university finally transitioned into a research university are: 1) the Republic Act 9500 of 2008 that overhauled the University Charter and made it into a national and research university; 2) the 2011 inaugural speech of the University President Alfredo Pascual; 3) the document University of the Philippines Strategic Plan 2011-2017 that was released by the Office of the President of the said university in 2012;4) the document A University of the Philippines Research Guidebook that was released by the Office of the Vice President for Academic Affairs in 2015; 5) the 2016 vision paper of Danilo Concepcion that led to his appointment as University President; and 6) some comparative publication data extracted from Scopus on August 14, 2017.

The 2008 New University Charter (Republic Act 9500): During the centenary of UP, the Philippine Congress crafted the law that would officially transform the university into a national and research university. The said document declares that the university shall: "serve as a research university in various fields of expertise and specialization by conducting basic and applied research and development, and promoting research in various colleges and universities, and contributing to the dissemination and application of knowledge" (Republic Act 9500, Section 3). The same document even emphasizes the Humboldtian idea that the research university should be there to serve the society: "The national university shall harness the expertise

(c) 2019 F.P.A. Demeterio III and Roland Theuas DS. Pada

https://www.kritike.org/journal/issue 24/demeterio\&pada june2019.pdf

ISSN 1908-7330

(c) $)$ BY-NC-ND 
of the members of its community and other individuals to regularly study the state of the nation in relation to its quest for national development in the primary areas of politics and economics, among others, identify key concerns, formulate responsive policies regarding these concerns, and give advice and recommendations to Congress and the President of the Philippines" (Republic Act 9500, Section 7). However, the charter appears to have missed mentioning two fundamental aspects of a research university, which is the unity of teaching and research, and the unity of professors and students in pursuing research.

The 2011 Inaugural Speech of Pascual: By 2010, UP as a system already had its current number of 8 autonomous constituent units, when the Cebu campus of UP Visayas was officially recognized as the eighth autonomous unit. The corporate executive Pascual was president of the university from 2011 to 2017. He studied in UP. Pascual did not elaborate on the research university. About five decades after Dyde coaxed the university to establish research-based graduate education to start its transition into a research university, and after Romulo talked and pushed for his plan to develop the graduate programs of the university in parallel with his envisioned intensification of research, Pascual's inaugural speech is suddenly back on the same track as he desired UP to become "a university that has a strong research capability, supported by an expanded graduate program, unshackled by sectarian constraints or commercial interests, and geared to addressing societal problems." 58

The 2012 Document University of the Philippines Strategic Plan 2011-2017: Aligned with Pascual's inaugural speech, this document emphasizes that to increase the university's research and creative output, the university, among other things, must increase the number of its graduate students. ${ }^{59}$ The document implies a plan for the university to transition towards the classic American model of a research university.

The 2015 Document A University of the Philippines Research Guidebook: In 2015, the Office of the Vice President for Academic Affairs of UP System released a document entitled A UP Research Guidebook. Seven years after the university was legislated to be a research university, it appears that it is still in the process of becoming one. The document admitted: "UP is a teaching and research university, yet it is organized more for teaching than

\footnotetext{
58 Alfredo Pascual, "President Pascual's Turnover Speech," in UP Newsletter: The University of the Philippines Newspaper, 32:2 (February 2011), 1.

${ }^{59}$ Office of the President of the University of the Philippines, University of the Philippines Strategic Plan 2011-2017 (Quezon City: University of the Philippines, 2012), 6.
}

(C) 2019 F.P.A. Demeterio III and Roland Theuas DS. Pada https://www.kritike.org/journal/issue 24/demeterio\&pada june2019.pdf ISSN 1908-7330 


\section{A HUMBOLDTIAN CRITIQUE}

for research. It still lacks a vigorous intensive and extensive research culture and focuses more on transferring knowledge rather than creating it." 60

The 2016 Vision Paper of Concepcion: The law professor Conception is the current president of the university since 2017. He studied in the Queen Mary University of London. As his inaugural speech was too short and did not tackle research, this paper analyzed the vision paper that he prepared that led to his appointment as University President. Concepcion also did not talk about the research university. Instead, he similarly merely problematized how to increase further the research output of the faculty members and how such output could impact the society. He wrote: "our goal is to craft research agenda heavily oriented toward addressing our country's problems and needs. We want UP researchers to see themselves as an active contributor to nation-building; and we want UP to be able to lend the proper environment that will ensure that their efforts come to fruition, for the nation's benefit." 61

14 August 2017 Comparative Publication Data from Scopus: There are three sets of data that this paper extracted from Scopus to show that nothing much had happened during the legislated transition of UP in 2008, in as far as the university's research output is concerned. The first set of data is presented in figure 3 and shows the aggregated annual publication output of the university's eight autonomous constituent units from 2001 to 2015.

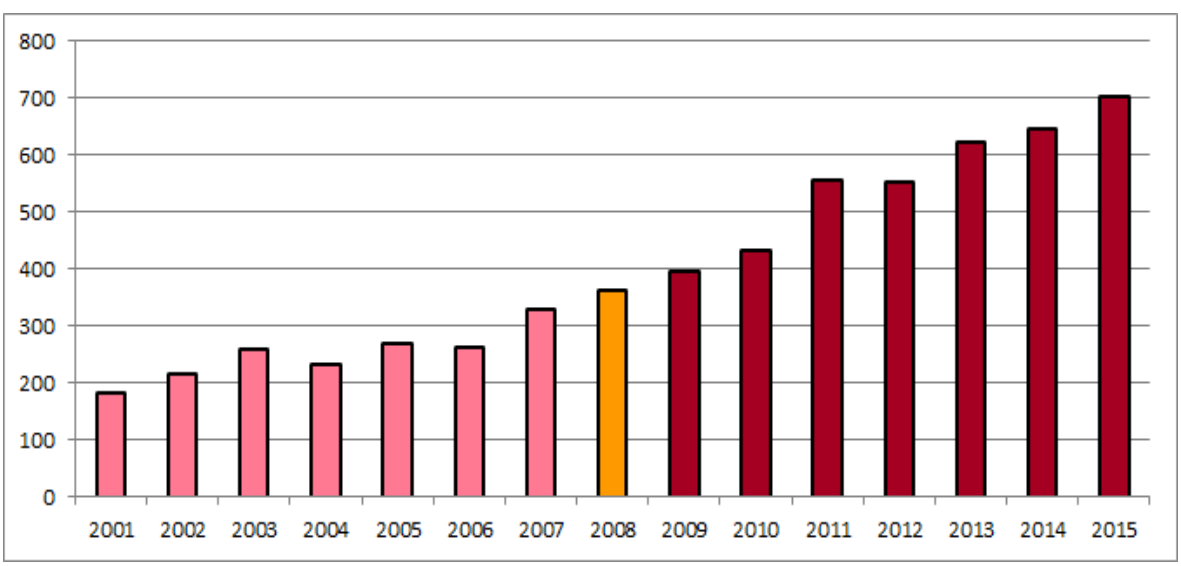

${ }^{60}$ Office of the Vice President for Academic Affairs of the University of the Philippines, A University of the Philippines Research Guidebook (Quezon City: University of the Philippines, 2015), 19.

${ }^{61}$ Danilo Concepcion, "Redefining the Culture of the University of the Philippines: Honor and Excellence with Compassion," (Diliman, Quezon City: Office of the Secretary of the University, 2016), http://osu.up.edu.ph/wp-content/uploads/2016/09/VISION_PROF.-DANILOL.-CONCEPCION.pdf, 30 July 2017.

(c) 2019 F.P.A. Demeterio III and Roland Theuas DS. Pada

https://www.kritike.org/journal/issue 24/demeterio\&pada june2019.pdf

ISSN 1908-7330

(cc) BY-NC-ND 
Figure 3: Annual Publication Output of UP from 2001 to 2015

(Based on Scopus Data as of 14 August 2017. See Appendix A for the Accompanying Table)

Figure 3 attempts to show the annual rate of increase of the university's publication output for us to see if there was a dramatic spike after the university transitioned into a research university in 2008. From 2001 to 2007, the annual rate of increase of the university's publication output was $11.21 \%$. From 2007 to 2015 , the annual rate of increase was $11.56 \%$. A difference of mere $0.35 \%$ clearly spells that nothing much has changed in the way the university produced its publications after 2008 .

The second set of data is presented in figure 4 and shows the aggregated annual per capita publication output of the university's eight autonomous constituent units from 2001 to 2016, in relation with the annual per capita publication output of the University of Santo Tomas, Ateneo de Manila University, and De La Salle University. UP and these three private universities constitute what is commonly known as the "Big Four" Philippine higher educational institutions. The numbers of academic staff listed in Quacquarelli Symonds 2016 University Ranking were used as the divisors for the annual Scopus publications of the four universities, specifically: 4,343 for UP, 1,888 for the University of Santo Tomas, 961 for Ateneo de Manila University, and 926 for De La Salle University. This paper merely assumed that such numbers of academic staff remained constant from 2001 to 2016.

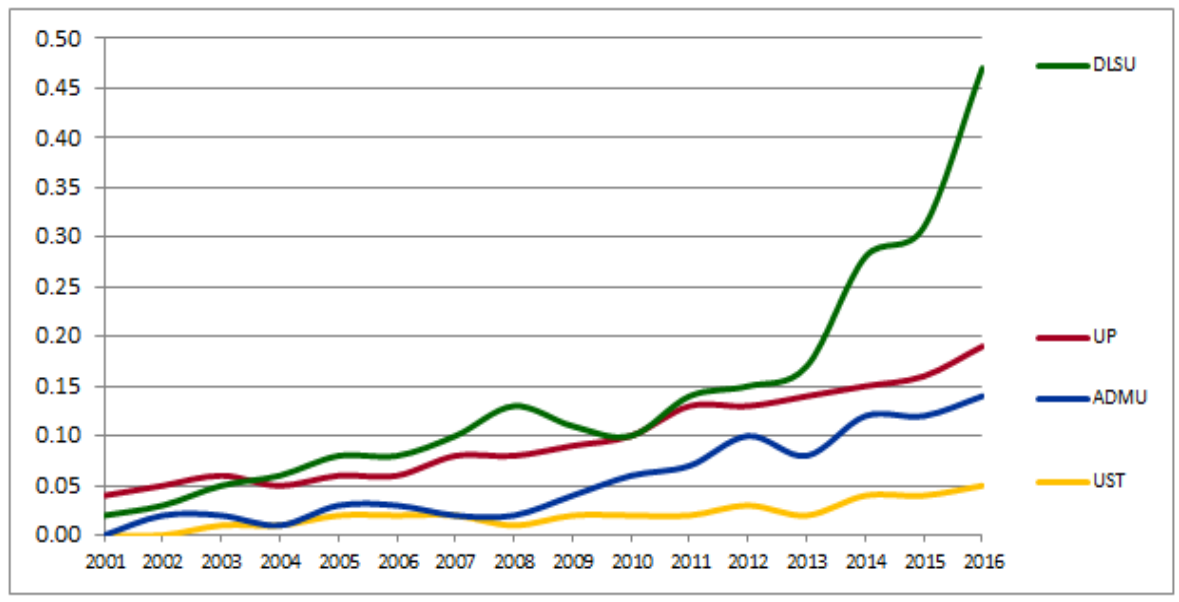

Figure 4: Annual Per Capita Publication Output of UP from 2001 to 2016, in Relation with those of the University of Santo Tomas, Ateneo de Manila University, and De La Salle University (Based on Scopus Data as of 14 August 2017, and the Quacquarelli Symonds Asian University Ranking 2016. See Appendix B for the Accompanying Table)

Figure 4 attempts to show that in terms of the steepness of the annual per capita publication output, the curve of UP behaved more or less the same

(c) 2019 F.P.A. Demeterio III and Roland Theuas DS. Pada https://www.kritike.org/journal/issue 24/demeterio\&pada june2019.pdf 


\section{A HUMBOLDTIAN CRITIQUE}

with that of Ateneo de Manila University, which is not a research university, and slightly better than that of the University of Santo Tomas, which is also not a research university. Figure 4 also attempts to show, as a point of comparison, how steep the curve of De La Salle University behaved after it transitioned into a research university in 2011. The four curves attest that nothing much has changed in the way UP produced its publications after 2008.

The third set of data is presented in figure 5 and shows the aggregated annual per capita publication output of the university's eight autonomous constituent units from 2001 to 2016, in relation with the annual per capita publication output of the twelve other ASEAN universities that made it to the 2016 list of top 100 Asian universities according to Quacquarelli Symonds. UP landed on rank 70, while the other twelve top ASEAN universities are: the National University of Singapore (rank 1), Nanyang Technological University (rank 3), the Universiti Malaya (rank 27), Chulalongkorn University (rank 45), the Universiti Putra Malaysia (rank 49), the Universiti Sains Malaysia (rank 51), the Universiti Kebangsaan Malaysia (rank 55), the Singapore Management University (rank 60), Mahidol University (rank 61), the Universiti Teknologi Malaysia (rank 63), the Universitas Indonesia (rank 67), and Ateneo De Manila University (rank 99). The numbers of academic staff listed in Quacquarelli Symonds 2016 University Ranking were used as the divisors for the annual Scopus publications of the thirteen universities.

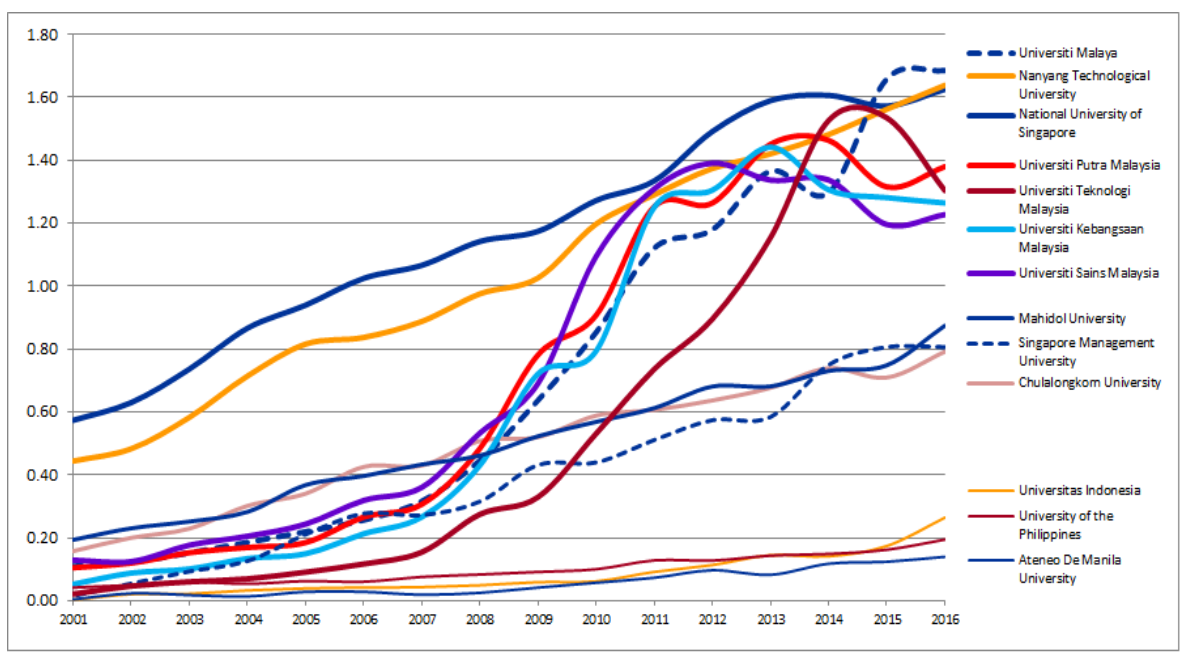

Figure 5: Annual Per Capita Publication Output of UP from 2001 to 2016, in Relation with those of the Twelve Other ASEAN Universities that Made it to the 2016 List of Top 100 Asian Universities according to Quacquarelli Symonds (Based on Scopus Data as of 14 August 2017, and the Quacquarelli Symonds Asian University Ranking 2016. See Appendix C for the Accompanying Table)

(c) 2019 F.P.A. Demeterio III and Roland Theuas DS. Pada https://www.kritike.org/journal/issue 24/demeterio\&pada june2019.pdf ISSN 1908-7330

(cc) BY-NC-ND 
Figure 5 attempts to show that in terms of the steepness of the annual per capita publication output, the curve of UP is left well below the curves of the really strong ASEAN research universities, the Universiti Malaya, Nanyang Technological University, the National University of Singapore, the Universiti Putra Malaysia, the Universiti Teknologi Malaysia, the Universiti Kebangsaan Malaysia, and the Universiti Sains Malaysia. Figure 5 also attempts to show that the curve of UP is also below the curves of most of the moderately strong ASEAN research universities, Mahidol University, the Singapore Management University, and Chulalongkorn University. Figure 5 also attempts to show that the curve of UP can only compete with the not so strong ASEAN research university, the Universitas Indonesia. This paper already mentioned that Ateneo de Manila University, although part of the top 100 ASEAN universities, is not a research university. Hence, in as far as the ASEAN standard of a research university, it appears that UP, and probably the Universitas Indonesia, have not made the proper transition.

Summation: The ongoing story of UP's period of transition into a research university appears to be a story of a nominal change that is yet to be accompanied by more tangible policy, organizational and pedagogical changes. The new charter of the university was not able to articulate what becoming a research university meant. It looked like the more than half a century old initiative of Romulo of using graduate education to boost university research simply did not take off, because Pascual mentioned the same strategy as if it is something new in the university. The data culled from Scopus suggest that there was nothing dramatic happened in 2008 in as far as the research productivity of the university is concerned. The period is still ongoing. It has almost been a decade that the university made its nominal transition. As the mandated model of a higher educational institution in the country, UP owes the Filipinos that it should do the actual policy, organizational and pedagogical transition into a research university sooner than later.

\section{Conclusion}

The story of the University of the Philippines has had its own developments, pitfalls, and progress that we can closely follow and develop by identifying the points in its story that could have led to its own claim as a research university. From its inception during the American colonial period, UP had its aspiration to transform itself into a research university in both the capabilities of its faculty and as well as its graduate program. Despite being entrenched in the task of providing education beyond its annual budgetary allocation, UP responded through the criticisms provided by the Monroe Commission to the extent that in the early 1930s, Alzona achieved tangible

(c) 2019 F.P.A. Demeterio III and Roland Theuas DS. Pada

https://www.kritike.org/journal/issue 24/demeterio\&pada june2019.pdf

ISSN 1908-7330

(cc) BY-NC-ND 


\section{A HUMBOLDTIAN CRITIQUE}

and remarkable results from the strengthening of the university's faculty research. UP has endured the storms of changes during the American occupation period; it has dealt with the great depression that has led to the decline of funding, as well as the devastation offered by the Second World War.

Rising from these calamities, the University, just like the public sector, used teaching and the civil service to keep the people employed as a response to the great depression. This period in the story of the University is a story of missed opportunities in its struggle to persist in hard times. For one, the University did not respond adequately to the demands of teaching and research. Instead of consolidating it as a unified activity between students and teachers in pursuit of research, the University dichotomized both activities as separate tasks. Instead of learning from the American translation of Humboldt's research university, the University turned to the nonHumboldtian pedagogical philosophy of Bruner. Adding to this, the AntiAmerican sentiments of the students and citizen unrests steered the university away from the well-established and proven American-style research university.

Coming from its liberation from the Americans, the University was now engaged in the task of transforming itself as a system. Consisting of eight autonomous units, the University, at this point, is unfolding its story as a growing teaching institution. While it has implemented a 12 unit per semester load to give room for research, the University has become aware of the dichotomized nature of research and teaching when the floodgates for external funding was opened to the University. For the first time, the actual idea of a "research" university came into the consciousness of UP and its administrators as they began to realize its potent role in the global academic scene. Feeling that UP is behind the ASEAN and Asian universities, the University was, by legislation, officially declared as a national research university. Despite changes in its policies and its charter, the documents presented in this paper show that the University was unable to articulate what it meant in its transition to a research university. The data gathered from the period of its declaration of transition in 2008 from Scopus, show that there is no significant or dramatic improvement in its research output.

The importance of the University of the Philippines in its role as a mandated model of higher education means that it should manifest the nominal title of research university into an actual policy, the organizational and pedagogical transition for the other Filipino university to follow. The University of the Philippine's divergence from the American translation of Humboldt's educational vision is a clear indication that its transition to the status of National Research University is merely a nominal one. Moreover,

(C) 2019 F.P.A. Demeterio III and Roland Theuas DS. Pada

https://www.kritike.org/journal/issue 24/demeterio\&pada june2019.pdf

ISSN 1908-7330

(cc) BY-NC-ND 
the system offered by Humboldt's educational system offers a stable, sustainable, progressive, and autonomous unity between stakeholders that advance the interests of the state, students, and professors in the pursuit of infinite knowledge. The evidence presented in this paper shows that the University of the Philippines, despite all the impasses and difficulties from its inception to the present day, has missed the opportunities to transform itself to a truly functional research university.

As a functional research university, the University of the Philippines should no longer have to contend with the issue surrounding its dichotomization of teaching and research, and even contending with the third element, extension work; it should not pose as a separate task that would occupy the time, effort, and resources of the University of the Philippines. The consequence of having these issues at the University of the Philippines is that it serves as a precedent and a model for all the other universities in the Philippines to follow. As an official state model of what a university is, laws, policies, and guidelines in higher education becomes modelled after the University of the Philippine's system. By going back to these issues and opportunities that the University of the Philippines has missed through over a hundred-year history, we hope that the University would open itself to the possibility of engaging in modelling talks. By engaging the University of the Philippines in this discourse, we can only hope that the University might adopt the Humboldtian model of higher education, be it an American rendition of the system, or a customized one to suit Philippine circumstances. While it is highly unlikely that the University can change its system overnight, opening a discourse about these issues can bring fruitful resolutions to existing educational problems in the Philippines. For example, should the University of the Philippines opt to pursue a specific type of Humboldtian model of research, it can now distribute the resources it has invested in its tripartite task of teaching, research, and extension services. This could mean that local state universities and colleges throughout the Philippines can focus on its role of training professionals, labourers, and technicians, while the University of the Philippines can concentrate on the pursuit of knowledge, which, in the end, is the actual goal of any teacher, student, researcher, and state in any educational institution. Despite this paper's archival critique of the University of the Philippines, our aim is not to insist on the University of the Philippines for what it is not. Rather, as a model institution for higher education in the Philippines, we reckon that this study can generate further discourse on the viability of Humboldt's model of education in the Philippines.

Department of Filipino, De La Salle University, Philippines Department of Philosophy, University of Santo Tomas, Philippines

(c) 2019 F.P.A. Demeterio III and Roland Theuas DS. Pada https://www.kritike.org/journal/issue 24/demeterio\&pada june2019.pdf ISSN 1908-7330 


\section{A HUMBOLDTIAN CRITIQUE}

\section{APPENDIX A}

\section{Annual Publication Output of UP from 2001 to 2015 (Based on Scopus Data as of 14 August 2017)}

\begin{tabular}{|c|c|c|c|c|c|c|c|c|c|}
\hline \multirow[b]{2}{*}{ Year } & \multicolumn{9}{|c|}{ Number of Publications } \\
\hline & $\begin{array}{l}\text { University } \\
\text { of the } \\
\text { Philippines } \\
\text { Diliman }\end{array}$ & $\begin{array}{c}\text { University of } \\
\text { the } \\
\text { Philippines } \\
\text { Manila }\end{array}$ & $\begin{array}{c}\text { University } \\
\text { of the } \\
\text { Philippines } \\
\text { Los Baños }\end{array}$ & $\begin{array}{l}\text { University } \\
\text { of the } \\
\text { Philippines } \\
\text { Visayas }\end{array}$ & $\begin{array}{c}\text { University } \\
\text { of the } \\
\text { Philippines } \\
\text { Baguio }\end{array}$ & $\begin{array}{c}\text { University } \\
\text { of the } \\
\text { Philippines } \\
\text { Mindanao }\end{array}$ & $\begin{array}{c}\text { University } \\
\text { of the } \\
\text { Philippines } \\
\text { Cebu }\end{array}$ & $\begin{array}{c}\text { University } \\
\text { of the } \\
\text { Philippines } \\
\text { Open } \\
\text { University }\end{array}$ & Total \\
\hline 2001 & 70 & 24 & 81 & 6 & 0 & 0 & 0 & 0 & 181 \\
\hline 2002 & 95 & 40 & 79 & 1 & 0 & 0 & 0 & 0 & 215 \\
\hline 2003 & 125 & 53 & 73 & 6 & 1 & 2 & 0 & 0 & 260 \\
\hline 2004 & 104 & 48 & 71 & 5 & 1 & 0 & 1 & 2 & 232 \\
\hline 2005 & 109 & 50 & 97 & 6 & 7 & 0 & 0 & 1 & 270 \\
\hline 2006 & 120 & 56 & 75 & 8 & 0 & 2 & 0 & 1 & 262 \\
\hline 2007 & 153 & 66 & 88 & 13 & 4 & 1 & 0 & 3 & 328 \\
\hline 2008 & 181 & 74 & 90 & 9 & 3 & 2 & 0 & 2 & 361 \\
\hline 2009 & 204 & 86 & 94 & 6 & 3 & 2 & 0 & 1 & 396 \\
\hline 2010 & 222 & 97 & 94 & 13 & 2 & 5 & 0 & 1 & 434 \\
\hline 2011 & 246 & 170 & 112 & 11 & 5 & 7 & 2 & 3 & 556 \\
\hline 2012 & 254 & 141 & 115 & 25 & 9 & 7 & 0 & 2 & 553 \\
\hline 2013 & 283 & 164 & 125 & 17 & 10 & 18 & 0 & 5 & 622 \\
\hline 2014 & 290 & 171 & 121 & 28 & 18 & 6 & 9 & 2 & 645 \\
\hline 2015 & 280 & 191 & 146 & 31 & 15 & 20 & 12 & 8 & 703 \\
\hline
\end{tabular}




\section{APPENDIX B}

Annual Per Capita Publication Output of UP from 2001 to 2016, in Relation with those of the University of Santo Tomas, Ateneo de Manila University, and De La Salle University (Based on Scopus Data as of 14 August 2017, and the Quacquarelli Symonds Asian University Ranking 2016).

\begin{tabular}{|c|c|c|c|c|c|c|c|c|c|c|c|c|}
\hline & University of the Philippines & \multicolumn{2}{|c|}{ University of Santo Tomas } & \multicolumn{2}{|c|}{ Ateneo de Manila University } & \multicolumn{2}{|c|}{ De La Salle University } \\
\cline { 2 - 13 } & $\begin{array}{c}\text { Publi- } \\
\text { cations }\end{array}$ & $\begin{array}{c}\text { Acade- } \\
\text { mic Staff }\end{array}$ & $\begin{array}{c}\text { Per } \\
\text { Capita } \\
\text { Publi- } \\
\text { cations }\end{array}$ & $\begin{array}{c}\text { Publi- } \\
\text { cations }\end{array}$ & $\begin{array}{c}\text { Acade- } \\
\text { mic Staff }\end{array}$ & $\begin{array}{c}\text { Per } \\
\text { Capita } \\
\text { Publi- } \\
\text { cations }\end{array}$ & $\begin{array}{c}\text { Publi- } \\
\text { cations }\end{array}$ & $\begin{array}{c}\text { Acade- } \\
\text { mic Staff }\end{array}$ & $\begin{array}{c}\text { Capita } \\
\text { Publi- } \\
\text { cations }\end{array}$ & $\begin{array}{c}\text { Publi- } \\
\text { cations } \\
\text { Acade- } \\
\text { Capic Staff } \\
\text { Publi- } \\
\text { cations }\end{array}$ \\
\hline 2001 & 181 & 4,343 & 0.04 & 7 & 1,888 & 0.00 & 4 & 961 & 0.00 & 20 & 926 & 0.02 \\
\hline 2002 & 215 & 4,343 & 0.05 & 6 & 1,888 & 0.00 & 22 & 961 & 0.02 & 29 & 926 & 0.03 \\
\hline 2003 & 260 & 4,343 & 0.06 & 17 & 1,888 & 0.01 & 17 & 961 & 0.02 & 43 & 926 & 0.05 \\
\hline 2004 & 232 & 4,343 & 0.05 & 12 & 1,888 & 0.01 & 13 & 961 & 0.01 & 60 & 926 & 0.06 \\
\hline 2005 & 270 & 4,343 & 0.06 & 36 & 1,888 & 0.02 & 27 & 961 & 0.03 & 75 & 926 & 0.08 \\
\hline 2006 & 262 & 4,343 & 0.06 & 30 & 1,888 & 0.02 & 27 & 961 & 0.03 & 71 & 926 & 0.08 \\
\hline 2007 & 328 & 4,343 & 0.08 & 33 & 1,888 & 0.02 & 18 & 961 & 0.02 & 88 & 926 & 0.10 \\
\hline 2008 & 361 & 4,343 & 0.08 & 27 & 1,888 & 0.01 & 24 & 961 & 0.02 & 124 & 926 & 0.13 \\
\hline 2009 & 396 & 4,343 & 0.09 & 30 & 1,888 & 0.02 & 40 & 961 & 0.04 & 98 & 926 & 0.11 \\
\hline 2010 & 434 & 4,343 & 0.10 & 41 & 1,888 & 0.02 & 55 & 961 & 0.06 & 95 & 926 & 0.10 \\
\hline 2011 & 556 & 4,343 & 0.13 & 33 & 1,888 & 0.02 & 70 & 961 & 0.07 & 129 & 926 & 0.14 \\
\hline 2012 & 553 & 4,343 & 0.13 & 61 & 1,888 & 0.03 & 93 & 961 & 0.10 & 139 & 926 & 0.15 \\
\hline 2013 & 622 & 4,343 & 0.14 & 44 & 1,888 & 0.02 & 79 & 961 & 0.08 & 158 & 926 & 0.17 \\
\hline 2014 & 645 & 4,343 & 0.15 & 77 & 1,888 & 0.04 & 113 & 961 & 0.12 & 259 & 926 & 0.28 \\
\hline 2015 & 703 & 4,343 & 0.16 & 80 & 1,888 & 0.04 & 119 & 961 & 0.12 & 289 & 926 & 0.31 \\
\hline 2016 & 844 & 4,343 & 0.19 & 92 & 1,888 & 0.05 & 134 & 961 & 0.14 & 433 & 926 & 0.47 \\
\hline
\end{tabular}




\section{APPENDIX C}

\section{Annual Per Capita Publication Output of UP from 2001 to 2016, in Relation with those of the Twelve Other ASEAN Universities that Made it to the 2016 List of Top 100 Asian Universities according to Quacquarelli Symonds (Based on Scopus Data as of 14 August 2017).}

\begin{tabular}{|c|c|c|c|c|c|c|c|c|c|c|c|c|c|c|}
\hline \multirow[t]{2}{*}{ Year } & $\begin{array}{l}\text { ASEAN } \\
\text { University }\end{array}$ & $\begin{array}{c}\text { National } \\
\text { University o } \\
\text { Singapore } \\
\end{array}$ & $\begin{array}{c}\text { Nanyang } \\
\text { echnologic: } \\
\text { I University }\end{array}$ & $\begin{array}{l}\text { Universiti } \\
\text { Malaya }\end{array}$ & $\begin{array}{l}\text { Chulalongko } \\
\text { n University }\end{array}$ & \begin{tabular}{|c} 
Universiti \\
Putra \\
Malaysia \\
\end{tabular} & $\begin{array}{c}\text { Universiti } \\
\text { Sains } \\
\text { Malaysia } \\
\end{array}$ & $\begin{array}{c}\text { Universiti } \\
\text { Kebangsaar } \\
\text { Malaysia } \\
\end{array}$ & $\begin{array}{c}\text { Singapore } \\
\text { Managemen } \\
\text { University }\end{array}$ & $\begin{array}{c}\text { Mahidol } \\
\text { University }\end{array}$ & $\begin{array}{l}\text { Universiti } \\
\text { Teknologi } \\
\text { Malaysia } \\
\end{array}$ & $\begin{array}{c}\text { Universitas } \\
\text { Indonesia }\end{array}$ & $\begin{array}{c}\text { fniversity o } \\
\text { the } \\
\text { Philippines }\end{array}$ & $\begin{array}{c}\text { Ateneo De } \\
\text { Manila } \\
\text { University }\end{array}$ \\
\hline & $\begin{array}{l}\text { Academic } \\
\text { Staff }\end{array}$ & 5,106 & 4,338 & 2,755 & 2,842 & 2,334 & 2,318 & 2,460 & 603 & 2,795 & 2,613 & 4,080 & 4,343 & 961 \\
\hline \multirow[t]{2}{*}{2001} & Publication & 2,927 & 1,925 & 302 & 448 & 245 & 299 & 129 & 9 & 541 & 56 & 11 & 181 & 4 \\
\hline & Per Capita & 0.57 & 0.44 & 0.11 & 0.16 & 0.10 & 0.13 & 0.05 & 0.01 & 0.19 & 0.02 & 0.00 & 0.04 & 0.00 \\
\hline \multirow[t]{2}{*}{2002} & Publication & 3,215 & 2,095 & 337 & 568 & 279 & 288 & 216 & 33 & 643 & 121 & 84 & 215 & 22 \\
\hline & Per Capita & 0.63 & 0.48 & 0.12 & 0.20 & 0.12 & 0.12 & 0.09 & 0.05 & 0.23 & 0.05 & 0.02 & 0.05 & 0.02 \\
\hline \multirow[t]{2}{*}{2003} & Publication & 3,758 & 2,527 & 419 & 651 & 356 & 409 & 248 & 56 & 703 & 157 & 89 & 260 & 17 \\
\hline & Per Capita & 0.74 & 0.58 & 0.15 & 0.23 & 0.15 & 0.18 & 0.10 & 0.09 & 0.25 & 0.06 & 0.02 & 0.06 & 0.02 \\
\hline \multirow[t]{2}{*}{2004} & Publication & 4,422 & 3,098 & 510 & 857 & 395 & 475 & 330 & 76 & 789 & 182 & 133 & 232 & 13 \\
\hline & Per Capita & 0.87 & 0.71 & 0.19 & 0.30 & 0.17 & 0.20 & 0.13 & 0.13 & 0.28 & 0.07 & 0.03 & 0.05 & 0.01 \\
\hline \multirow[t]{2}{*}{2005} & Publication & 4,796 & 3,538 & 604 & 967 & 431 & 564 & 367 & 127 & 1,027 & 237 & 160 & 270 & 27 \\
\hline & Per Capita & 0.94 & 0.82 & 0.22 & 0.34 & 0.18 & 0.24 & 0.15 & 0.21 & 0.37 & 0.09 & 0.04 & 0.06 & 0.03 \\
\hline \multirow[t]{2}{*}{2006} & Publication & 5,232 & 3,630 & 706 & 1,209 & 620 & 739 & 523 & 167 & 1,108 & 305 & 170 & 262 & 27 \\
\hline & Per Capita & 1.02 & 0.84 & 0.26 & 0.43 & 0.27 & 0.32 & 0.21 & 0.28 & 0.40 & 0.12 & 0.04 & 0.06 & 0.03 \\
\hline \multirow[t]{2}{*}{2007} & Publication & 5,443 & 3,851 & 871 & 1,221 & 715 & 835 & 654 & 164 & 1,210 & 403 & 175 & 328 & 18 \\
\hline & Per Capita & \begin{tabular}{|l|}
1.07 \\
\end{tabular} & 0.89 & 0.32 & 0.43 & 0.31 & 0.36 & 0.27 & 0.27 & 0.43 & 0.15 & 0.04 & 0.08 & 0.02 \\
\hline \multirow[t]{2}{*}{2008} & Publication & 5,831 & 4,231 & 1,226 & 1,443 & 1,129 & 1,235 & 1,058 & 190 & 1,289 & 717 & 200 & 361 & 24 \\
\hline & Per Capita & 1.14 & 0.98 & 0.45 & 0.51 & 0.48 & 0.53 & 0.43 & 0.32 & 0.46 & 0.27 & 0.05 & 0.08 & 0.02 \\
\hline \multirow[t]{2}{*}{2009} & Publication & 5,994 & 4,450 & 1,755 & 1,478 & 1,824 & 1,601 & 1,774 & 260 & 1,461 & 860 & 240 & 396 & 40 \\
\hline & Per Capita & 1.17 & 1.03 & 0.64 & 0.52 & 0.78 & 0.69 & 0.72 & 0.43 & 0.52 & 0.33 & 0.06 & 0.09 & 0.04 \\
\hline \multirow[t]{2}{*}{2010} & Publication & 6,495 & 5,194 & 2,350 & 1,672 & 2,118 & 2,537 & 1,952 & 265 & 1,589 & 1,387 & 252 & 434 & 55 \\
\hline & Per Capita & 1.27 & 1.20 & 0.85 & 0.59 & 0.91 & 1.09 & 0.79 & 0.44 & 0.57 & 0.53 & 0.06 & 0.10 & 0.06 \\
\hline \multirow[t]{2}{*}{2011} & Publication & 6,815 & 5,597 & 3,088 & 1,724 & 2,924 & 3,035 & 3,077 & 308 & 1,711 & 1,923 & 374 & 556 & 70 \\
\hline & Per Capita & 1.33 & 1.29 & 1.12 & 0.61 & 1.25 & 1.31 & 1.25 & 0.51 & 0.61 & 0.74 & 0.09 & 0.13 & 0.07 \\
\hline \multirow[t]{2}{*}{2012} & Publication & 7,615 & 5,960 & 3,249 & 1,809 & 2,950 & 3,223 & 3,210 & 346 & 1,903 & 2,339 & 462 & 553 & 93 \\
\hline & Per Capita & 1.49 & 1.37 & 1.18 & 0.64 & 1.26 & 1.39 & 1.30 & 0.57 & 0.68 & 0.90 & 0.11 & 0.13 & 0.10 \\
\hline \multirow[t]{2}{*}{2013} & Publication & 8,115 & 6,160 & 3,761 & 1,923 & 3,386 & 3,099 & 3,546 & 352 & 1,904 & 3,015 & 590 & 622 & 79 \\
\hline & Per Capita & 1.59 & 1.42 & 1.37 & 0.68 & 1.45 & 1.34 & 1.44 & 0.58 & 0.68 & 1.15 & 0.14 & 0.14 & 0.08 \\
\hline \multirow[t]{2}{*}{2014} & Publication & 8,202 & 6,429 & 3,572 & 2,100 & 3,415 & 3,100 & 3,213 & 452 & 2,041 & 3,989 & 575 & 645 & 113 \\
\hline & Per Capita & 1.61 & 1.48 & 1.30 & 0.74 & 1.46 & 1.34 & 1.31 & 0.75 & 0.73 & 1.53 & 0.14 & 0.15 & 0.12 \\
\hline \multirow[t]{2}{*}{2015} & Publication & 8,028 & 6,776 & 4,568 & 2,016 & 3,070 & 2,772 & 3,152 & 486 & 2,091 & 4,011 & 709 & 703 & 119 \\
\hline & Per Capita & 1.57 & 1.56 & 1.66 & 0.71 & 1.32 & 1.20 & 1.28 & 0.81 & 0.75 & 1.54 & 0.17 & 0.16 & 0.12 \\
\hline \multirow[t]{2}{*}{2016} & Publication & 8,300 & 7,108 & 4,643 & 2,249 & 3,220 & 2,845 & 3,110 & 486 & 2,444 & 3,406 & 1,077 & 844 & 134 \\
\hline & Per Capita & 1.63 & 1.64 & 1.69 & 0.79 & 1.38 & 1.23 & 1.26 & 0.81 & 0.87 & 1.30 & 0.26 & 0.19 & 0.14 \\
\hline
\end{tabular}




\section{References}

Abueva, Jose, Reinventing UP as the National University: Learning for Truth, Leadership, and Social Transformation (Quezon City: University of the Philippines, 2008).

Act No. 1870, An Act for the Purpose of Founding a University for the Philippine Islands, Giving It Corporate Existence, Providing for a Board of Regents, Defining the Board's Responsibilities and Duties, Providing Higher Professional Instruction, and for Other Purposes (1908).

Act No. 3608, An Act Endowing the University of the Philippines with Portions of Lands of the Public Domain for Additional Support and Maintenance, and for other Purposes (1930).

Adams Act of 1906, An Act to Provide for an Increased Annual Appropriation for Agricultural Experiment Stations and Regulating the Expenditure Thereof (1906).

Altbach, Philip, "The Past, Present, and Future of the Research University," in The Road to Academic Excellence: The Making of World-Class Research Universities, ed. by Philip Altbach and Jamil Salmi (Washington, D.C.: The World Bank, 2011).

Alzona, Encarnacion, A History of Education in the Philippines, 1565-1930 (Manila: University of the Philippines Press, 1932).

Bartlett, Murray, "A University for the Filipino," in The Role and Mission of the University: Inaugural Addresses of the Presidents of the University of the Philippines, ed. by Consuelo Fonacier (Quezon City: University of the Philippines Press, 1971).

Bauzon, Leslie, "Angara's Tough Minded Leadership: The Diamond Jubilee Highlighted by Reform of the University System," in University of the Philippines: The First 75 Years (1908-1983), ed. by Oscar Alfonso (Quezon City: University of the Philippines, 1985).

Benton, Guy Potter, "Objectives of the University," in The Role and Mission of the University: Inaugural Addresses of the Presidents of the University of the Philippines, ed. by Consuelo Fonacier (Quezon City: University of the Philippines Press, 1971).

Bocobo, Jorge, "Presidential Inaugural Address," in The Role and Mission of the University: Inaugural Addresses of the Presidents of the University of the Philippines, ed. by Consuelo Fonacier (Quezon City: University of the Philippines Press, 1971).

Carson, Arthur, Higher Education in the Philippines (Washington, D.C.: United States Printing Office, 1961).

Clark, William, Academic Charisma and the Origins of the Research University (Chicago: University of Chicago Press, 2006).

(c) 2019 F.P.A. Demeterio III and Roland Theuas DS. Pada https://www.kritike.org/journal/issue 24/demeterio\&pada june2019.pdf ISSN 1908-7330 


\section{A HUMBOLDTIAN CRITIQUE}

Concepcion, Danilo, "Redefining the Culture of the University of the Philippines: Honor and Excellence with Compassion," (Diliman, Quezon City: Office of the Secretary of the University, 2016), http://osu.up.edu.ph/wp-content/uploads/2016/09/VISION PROF.DANILO-L.-CONCEPCION.pdf, 30 July 2017.

Dhondt, Pieter, "Humboldt in Belgium: Rhetoric on the German University Model," The Humboldtian Tradition: Origins and Legacies, ed. by Peter Josephson, Thomas Karlsohn, and Johan Östling (Leiden: Brill Academic Publishers, 2014).

Doeppers, Daniel F, "Metropolitan Manila in the Great Depression: Crisis for Whom?" The Journal of Asian Studies, 50:3 (August 1991).

Dyde, Walter, A Report on Graduate Education in the Philippines (Quezon City: Graduate College of Education, University of the Philippines, 1962).

Education Division, USOM to the Philippines, A Report of a Decade of U.S. Assistance to Public Education in the Philippines: The 10th Milestone Manila 1962 (Manila: USOM to the Philippines, Agency for Internationl Development, 1961).

Endriga, Jose, “Corpuz and Soriano's Bifocal Administrations: Toward a Realignment of the Academe to National Realities under a Crisis Government," in University of the Philippines: The First 75 Years (19081983), ed. by Oscar Alfonso (Quezon City: University of the Philippines, 1985).

Evangelista, Oscar, "Lopez's Beleaguered Tenure: Barricades on Campus at the Peak of Student Discontent," University of the Philippines: The First 75 Years (1908-1983), ed. by Oscar Alfonso (Quezon City: University of the Philippines, 1985).

Fallon, Daniel, "German Influences on American Education," in The GermanAmerican Encounter: Conflict and Cooperation Between Two Cultures, ed. by Frank Trommler \& Elliott Shore (New York: Berghahn Books, 2002).

Fincher, Cameron, The Influence of British and German Universities on the Historical Development of American Universities (Athens, Georgia: Institute of Higher Education, University of Georgia, 1996).

Fores-Ganzon, Guadalupe, "Research," in Reappraisal and Rededication: Papers and Proceedings, 1966 UP Faculty Conference, ed. by Hernando Abaya. (Quezon City: University of the Philippines, 1966).

Geiger, Roger, To Advance Knowledge: The Growth of American Research Universities, 1900-1940 (New York: Oxford University Press, 1986).

Gonzalez, Bienvenido, "A University for the Philippines," in The Role and Mission of the University: Inaugural Addresses of the Presidents of the University of the Philippines, ed. by Consuelo Fonacier (Quezon City: University of the Philippines Press, 1971).

(c) 2019 F.P.A. Demeterio III and Roland Theuas DS. Pada

https://www.kritike.org/journal/issue 24/demeterio\&pada june2019.pdf

ISSN 1908-7330

(cc) BY-NC-ND 
Harris-Huemmert, Susan, Evaluating Evaluators: An Evaluation of Education in Germany (Wiesbaden: VS Verlag für Sozialwissenschaften, 2011).

Hatch Act of 1887, An Act to Establish Agricultural Experiment Stations in Connection with the Colleges Established in the Several States under the Provisions of an Act Approved July Second, Eighteen Hundred and Sixty-Two, and of the Acts Supplementary Thereto, 7 U.S.C. $\S$ 361 (1887).

von Humboldt, Wilhelm. "On the Internal and External Organization of the Higher Scientific Institutions in Berlin," in German History in Documents and Images, Vol. 1, From Absolutism to Napoleon (16481815), ed. by William Hagen (Washington, D.C.: German Historical Institute, n.d.), http://germanhistorydocs.ghidc.org/sub document.cfm?document id=3642, 30 July 2017.

Javier, Emil, "U.P. in the Service of the Nation: Recapturing the Sense of National Purpose," in The Investiture of Dr. Emil Q. Javier as Sixteenth President of the University of the Philippines (Quezon City: University of the Philippines, 1994).

Jay, Martin, Dialectical Imagination: A History of the Frankfurt School and the Institute of Social Research 1923-1950 (London: Heinemann Educational Books, 1976).

Josephson, Peter, "The Publication Mill: The Beginnings of Publication History as an Academic Merit in German Universities, 1750-1810," in The Humboldtian Tradition: Origins and Legacies, ed. by Peter Josephson, Thomas Karlsohn, and Johan Östling (Leiden: Brill Academic Publishers, 2014).

Klencke, Hermann, and Gustav Schlesier, Lives of the Brothers Humboldt, Alexander and William (London: Ingram, Cooke and Company, 1852).

Liedman, Sven-Eric, "In Search of Isis: General Education in Germany and Sweden," in The European and American University Since 1800: Historical and Sociological Essays, ed. by Sheldon Rothblatt and Bjorn Wittrock (Cambridge: Cambridge University Press, 1993).

Lopez, Salvador, "The University as Social Critic and Agent of Change," in The Role and Mission of the University: Inaugural Addresses of the Presidents of the University of the Philippines, ed. by Consuelo Fonacier (Quezon City: University of the Philippines Press, 1971).

Monroe, Paul, A Survey of the Educational System of the Philippine Islands by the Board of Educational Survey, Created under Acts 3162 and 3196 of the Philippine Legislature (Manila: Bureau of Printing, 1925).

Morales, Alfredo, "Our Goal of Quality Education," in Reappraisal and Rededication: Papers and Proceedings, 1966 UP Faculty Conference, ed. by Hernando Abaya (Quezon City: University of the Philippines, 1966).

(c) 2019 F.P.A. Demeterio III and Roland Theuas DS. Pada https://www.kritike.org/journal/issue 24/demeterio\&pada june2019.pdf ISSN 1908-7330 


\section{A HUMBOLDTIAN CRITIQUE}

Morgan, Keith, "Where is von Humboldt's University Now?" in Research in Higher Education-Daigaku Ronshu, 42 (March 2011).

Morrill Act of 1862, An Act Donating Public Lands to the Several States and Territories which May Provide Colleges for the Benefit of Agriculture and the Mechanic Arts, 7 U.S.C. § 304-309 (1862).

Nemenzo, Francisco, UP into the 21st Century and other Essays (Quezon City: University of the Philippines Press, 2000).

Office of the President of the University of the Philippines, University of the Philippines Strategic Plan 2011-2017 (Quezon City: University of the Philippines, 2012).

Office of the Vice President for Academic Affairs of the University of the Philippines, Shaping our Institutional Future: A Statement on Faculty Tenure, Rank and Promotion (Quezon City: University of the Philippines, 2004).

Office of the Vice President for Academic Affairs of the University of the Philippines, A University of the Philippines Research Guidebook (Quezon City: University of the Philippines, 2015).

Palma, Rafael, "Inaugural Address," in The Role and Mission of the University: Inaugural Addresses of the Presidents of the University of the Philippines, ed. by Consuelo Fonacier (Quezon City: University of the Philippines Press, 1971).

Pascual, Alfredo, "President Pascual's Turnover Speech," in UP Newsletter: The University of the Philippines Newspaper, 32:2 (February 2011).

Peters, Michael. "On Narratives of Self-Formation and Education," Psychosociological Issues in Human Resource Management, 3:2 (2015).

Presidential Decree No. 58, Constituting the University of the Philippines at Los Banos, Granting It Full and Complete Autonomy, and Amending the Charter of the University of the Philippines (1972).

"QS University Rankings: Asia 2016," in QS Top Universities, https://www.topuniversities.com/university-rankings/asianuniversity-rankings/2016, 14 August 2017.

Republic Act 9500, An Act to Strengthen the University of the Philippines as the National University (2008).

Revised Code of the University of the Philippines (Diliman, Quezon City: U.P. Law Center, 1975), http://osu.up.edu.ph/wpcontent/uploads/2014/05/UNIVERSITY-CODE-1961 1.pdf, 30 July 2017.

Roman, Emerlinda, "The University of the Philippines: A National University in the 21st Century," in The University of the Philippines Gazette, 36:3 (July-September 2005).

Romulo, Carlos, "Toward the Best University for the Filipino," in The Role and Mission of the University: Inaugural Addresses of the Presidents of the

(c) 2019 F.P.A. Demeterio III and Roland Theuas DS. Pada

https://www.kritike.org/journal/issue 24/demeterio\&pada june2019.pdf

ISSN 1908-7330

(c) $)$ BY-NC-ND 
University of the Philippines, ed. by Consuelo Fonacier (Quezon City: University of the Philippines Press, 1971).

Sinco, Vicente, "The University of the Philippines and its Mission," in The Role and Mission of the University: Inaugural Addresses of the Presidents of the University of the Philippines, ed. by Consuelo Fonacier (Quezon City: University of the Philippines Press, 1971).

Smith-Lever Act of 1914, An Act to Provide for Cooperative Agricultural Extension Work between the Agricultural Colleges in Several States Receiving the Benefits of an Act of Congress approved July Second, Eighteen Hundred and Sixty-Two, and of Acts Supplementary Thereto, and the United States Department of Agriculture, 7 U.S.C $\S$ 341-349 (1914).

Tan, Vidal, "The Role of our State University," in The Role and Mission of the University: Inaugural Addresses of the Presidents of the University of the Philippines. ed. by Consuelo Fonacier (Quezon City: University of the Philippines Press, 1971).

Trommler, Frank, "Recovering the History of Germanics in the United States: an Exploration," in Teaching German in Twentieth-Century America, ed. by David Benseler, Craig Nickisch, and Cora Lee Nollendorfs (Madison, WI: University of Wisconsin Press, 2001).

United States Office of Mission to the Philippines, The Tenth Milestone: A Report of a Decade of U.S. Assistance to Public Education in the Philippines, 1952-1962 (Manila: United States Office of Mission to the Philippines, Agency for International Development, 1962).

Valenzuela, Victor, "Graduate Education," in Reappraisal and Rededication: Papers and Proceedings, 1966 UP Faculty Conference, ed. by Hernando Abaya (Quezon City: University of the Philippines, 1966).

Van de Graaff, John Hargrove, The Politics of German University Reform, 18191979 (New York: Columbia University, 1973).

Villamor, Ignacio, "The University and the People," in The Role and Mission of the University: Inaugural Addresses of the Presidents of the University of the Philippines, ed. by Consuelo Fonacier (Quezon City: University of the Philippines Press, 1971).

Wellmon, Chad, Organizing Enlightenment: Information Overload and the Invention of the Modern Research University (Baltimore, MD: Johns Hopkins University Press, 2016).

Ziolkowski, Theodore, "The Nineteenth-Century German University and German Idealism," in Reexamining Academic Freedom in Religiously Affiliated Universities: Transcending Orthodoxies, ed. by Kenneth Garcia (Cham: Palgrave Macmillan, 2016).

(C) 2019 F.P.A. Demeterio III and Roland Theuas DS. Pada https://www.kritike.org/journal/issue 24/demeterio\&pada june2019.pdf ISSN 1908-7330 